\title{
Apedilum griseistriatum comb. nov., placement of Chironomus (Polypedilum) griseistriatum (Diptera, Chironomidae)
}

\author{
Mariano Donato', Augusto Siri', Julieta Massaferro² \& Stephen J. Brooks ${ }^{3}$
}

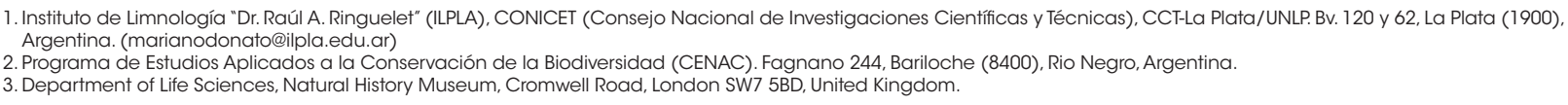

ABSTRACT. The study of the type material of Chironomus (Polypedilum) griseistriatum Edwards, 1931 described from Patagonia lead us to formally transfer the species to Apedilum Townes, 1945 as a new combination, and a reared specimen allows us to describe its pupa. Based on several larvae belonging to Apedilum collected in the proximity of the localities in which the adults and pupae were found, we tentatively describe the larval stage. Subfossil larval head capsules of the same species were found in Laguna Stibnite at $46^{\circ} \mathrm{S}$ in Chile dated to about 2,500 years ago and in Puerto Blest, Lago Nahuel Huapi at $41^{\circ} \mathrm{S}$ in Argentina dated about 2,000 years ago. We discuss the habitat of the species based on both modern and subfossil material. Identification keys to male adult, pupae and fourth instar larvae are also provided.

KEYWORDS. Apedilum, Chironominae, new combination, Subantarctic forest, Patagonia.

RESUMEN. Apedilum griseistriatum comb. nov., colocación de Chironomus (Polypedilum) griseistriatum (Diptera, Chironomidae). El estudio del material tipo de Chironomus (Polypedilum) griseistriatum Edwards, 1931 de Patagonia nos permite transferir formalmente la especie a Apedilum Townes, 1945 como una nueva combinación, y la cría de un especimen nos permite describir su pupa. Sobre la base de varias larvas pertenecientes a Apedilum colectadas en las proximidades de las localidades en las cuales fueron encontrados los adultos y las pupas, describimos tentativamente el estadio larval. Cápsulas de larvas subfósiles de la misma especie fueron encontradas en la Laguna Stibnite a $46^{\circ} \mathrm{S}$ en Chile datadas en aproximadamente 2.500 años atrás y en Puerto Blest, Lago Nahuel Huapi a $41^{\circ} \mathrm{S}$ en Argentina datadas en aproximadamente 2.000 años atrás. Discutimos el hábitat de la especie basados en el material moderno y subfósil. Se provee además de claves de identificación del cuarto estadio larval, pupa y adulto macho.

PALABRAS ClAVE. Apedilum, Chironominae, nueva combinación, Bosque Subantártico, Patagonia.

The genus Apedilum was first described by TownES (1945) to include two species, $A$. elachistum and $A$. subcinctum. In the same work, the author established that Chironomus nigrohalteralis Malloch, 1915 and Chironomus (Lauterborniella) brachylabis Edwards, 1929 were synonyms and proposed a new combination, Apedilum nigrohalterale (Maloch). Previously, Lenz (1941) had proposed the genus Paralauterborniella for Chironomus (Lauterborniella) brachylabis. Rоваск (1957), in a footnote in a key, mentioned Lenz's 1941 paper and considered Apedilum a junior synonym of Paralauterborniella. EPLER (1988), based on characters from all life stages, resurrected the genus Apedilum as a legitimate genus made up of two species, A. elachistum and A. subcinctum. Consequently, Paralauterborniella became a monotypic genus.

Apedilum is widely distributed in North and South America. The species $A$. subcinctum occurs in the Nearctic region and A. elachistum is present in the Nearctic and Neotropics. Recently, Donato et al. (2008) analyzed the geographical variation of $A$. elachistum.

Our re-examination of the type material of Chironomus (Polypedilum) griseistriatum described by EDWARDS (1931) from Patagonia lead us to formally transfer this species to Apedilum as a new combination and reared specimens allow us to describe its pupa. Based on several larvae belonging to Apedilum collected in the proximity of the localities in which the adults and pupae were found, we tentatively describe the larval stage of this species. Subfossil head capsules of Apedilum were recovered from sediment cores from several shallow lakes. We compared these morphotypes with the modern specimens of Apedilum found in northern Patagonia.

\section{MATERIAL AND METHODS}

The type material of Chironomus (Polypedilum) griseistriatum is deposited in the Natural History Museum, London (NHM, UK). The holotype male is pinned with its hypopygium mounted in Canada balsam and the male paratype is mounted in Euparal. The new specimens we have studied are deposited in Museo de La Plata (Argentina, MLP), Programa de Estudios Aplicados a la Conservación de la Biodiversidad (CENAC/APN) and NHM.

The morphological nomenclature follows S (1980) and EPLER (1987). All measurements in this study are in $\mu \mathrm{m}$ unless stated otherwise and are given as ranges followed by the measurement of the paratype.

\section{RESULTS}

\author{
Apedilum griseistriatum (Edwards, 1931), \\ comb. nov.
}

Chironomus (Polypedilum) griseistriatum EDWARDs, 1931:316. 
Material examined. ARGENTINA, Terr. Rio Negro: L. Gutierrez, Holotype đิ, 3/14.11.1926, F. \& M. Edwards col. (NHM); Terr. Rio Negro: L. Correntoso, Paratype đ̄, 18/25.11.1926, F. \& M. Edwards col. (NHM); Río Negro: P. N. Nahuel Huapi, (Blest stream

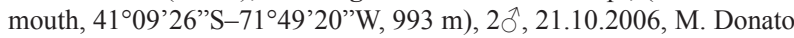
col. (MLP); (Lago Gutierrez, Playa Muñoz, $41^{\circ} 13^{\prime} 09^{\prime \prime} \mathrm{S}-71^{\circ} 26^{\prime} 0.5^{\prime \prime} \mathrm{W}$, $815 \mathrm{~m}$ ), ふै, 19.2.2006, M. Donato col. (NHM); (Laguna Los Clavos, 4102'48.6”'S-7149'33.9”'W, 1194 m), 4 pupal exuviae, 3.3.2007, M. Donato col. (MLP); Same data, 4 larvae, 3.3.2007, A. Garré \& F. Montes de Oca col. (MLP); Chubut: P. N. Los Alerces (Lago Futalaufken,

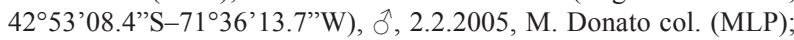
(Lago Espejo, 4041'06.7'S-7141'39.9”W), ơ, 8.2.2005, M. Donato col. (MLP). CHILE, XI Region: Laguna Stibnite ( $46^{\circ} 25^{\prime}$ 'S $\left.-74^{\circ} 24^{\prime} \mathrm{W}\right)$, 15 subfossil larvae, 1993, K. Benneth col. (NHM).

Other material studied but not included in the redescription. Río Negro: P. N. Nahuel Huapi, (Lago Nahuel Huapi, Blest branch, $41^{\circ} 01^{\prime} 22^{\prime}$ 'S, 71 $\left.{ }^{\circ} 49^{\prime} 06^{\prime} \mathrm{W}, 800 \mathrm{~m}\right), 8$ larvae, 4.2.2012, N. Serra \& J. Massaferro, col. (CENAC/APN).

Diagnosis. The male of Apedilum griseistriatum is clearly differentiated from the rest of the species of the genus by having the wing without pale spots, anal point always present with its length greater than the maximum width of superior volsella and gonostylus greatly inflated. The pupa of A. griseistriatum is separated from the rest of the members of the genus by the absence of shagreen on T VII and VIII and dorsal shagreen on T II-VI subquadrate with its median area bare. The presence of 74-81 maxillary plate striae on the ventromental plate separates $A$. griseistriatum from the rest of the larvae of the genus.

Male imago ( $n=7$ except when otherwise stated) (Figs 1-5). Total length 2.85-4.32 [4.32] mm. Thorax length $0.76-1.12$ [1.12] mm. Abdomen length 2-3.2 [3.2] mm. Total length/wing length 1.41-1.93 [1.75] (6), wing length/ profemur length 2.21-2.74 [2.21] (6). Coloration: Head, thorax, and abdomen mostly dark brown, with brownish legs. Wing membrane whitish.

Head. AR 0.97-1.32 (4). Antennae with 13 flagellomeres, ultimate flagellomere 450-520 (4) long. Tentorium 140-191 [191] (6) long, 34-64 [56] (6) width. Temporal setae 8-11 [11] (6); Clypeus with 9-14 [12] (6) setae. Palpomere lengths: 28-36 (2), 34-36 (2), 82-110 (2), 80-120 (2), 128-178 (2).

Thorax (Fig. 1). Acrostichals 8-14 [11] (4); Dorsocentrals 7-11 [8]; Prealars 1-2 [2]. Scutellum with 7-9 [7] setae.

Wing (Fig. 2). Without pale spots. Wing length 1.78-2.47 [2.47] (6) mm; width 0.52-0.62 [0.62] (6) $\mathrm{mm}$. VR 1.21-1.36 [1.36] (6). $\mathrm{R}$ with 15-23 [23] (6) setae, $\mathrm{R}_{1}$ with 10-13 [13] (6) setae. $R_{4+5}$ with 22-40 [36] (6) setae. Squama bare.

Legs. Apex of fore tibia blunt, with scarcely produced scale without apical spur; mid tibia with combs 16-26 (5) long, spur 34-46 (5) long; hind tibia with combs 18-32 long, with spur 40-46 long. Without palmate sensilla chaetica on mid and hind metatarsus. Width at apex of front tibia 44-51 [51] (6); of middle tibia 50-60 [60] (6); of hind tibia 54-70 [70] (6). Lengths and proportion of legs in Table I.
Tab. I. Lengths (in mm) and proportions of legs of Apedilum griseistriatum (Edwards, 1931) ( $n=6$ except when otherwise stated).

\begin{tabular}{|c|c|c|c|}
\hline & $\mathrm{fe}$ & $\mathrm{ti}$ & $\mathrm{ta}_{1}$ \\
\hline $\mathrm{p}_{1}$ & $750-830,800$ & $620-710,650$ & $790-860(2)$ \\
\hline $\mathrm{p}_{2}$ & $800-900,833$ & $670-740,697$ & $420-470,437$ \\
\hline \multirow[t]{2}{*}{$\mathrm{p}_{3}$} & $900-1000,933$ & $810-920,850$ & $570(2)$ \\
\hline & $\mathrm{ta}_{2}$ & $\mathrm{ta}_{3}$ & $\mathrm{ta}_{4}$ \\
\hline $\mathrm{p}_{1}$ & 400- $430(2)$ & $320-340$ & $220-230(2)$ \\
\hline $\mathrm{p}_{2}$ & $220-260,233$ & $170-200,180$ & $100-120,110$ \\
\hline \multirow[t]{2}{*}{$\mathrm{p}_{3}$} & $350(2)$ & $290-300(2)$ & $150-160(2)$ \\
\hline & $\mathrm{ta}_{5}$ & LR & BV \\
\hline $\mathrm{p}_{1}$ & $130(1)$ & $1.27-1.39(2)$ & $1.97(1)$ \\
\hline $\mathrm{p}_{2}$ & $80-100(2)$ & $0.62-0.64,0.63$ & $3.15-3.33(2)$ \\
\hline $\mathrm{p}_{3}$ & $100(2)$ & 0.69- 0.7 (2) & $2.53-2.54(2)$ \\
\hline \multicolumn{4}{|c|}{ SV } \\
\hline $\mathrm{p}_{1}$ & $1.59-1.83(2)$ & & \\
\hline $\mathrm{p}_{2}$ & $3.49-3.52,3.5$ & & \\
\hline $\mathrm{p}_{3}$ & 3- $3.01(2)$ & & \\
\hline
\end{tabular}

Hypopygium (Figs 3-5). With anal point (Fig. 4), 2-4 [2] apical anal setae on tergum IX. Laterosternite IX with 1-4 [1] setae. Segment VIII not tapered basally. Phallapodeme 51-72 [71] long; transverse sternapodeme $29-50$ [44] long. Gonocoxite 120-162 [132] long. Superior volsella globose, without microtrichia, bearing several large microtrichia on mesal surface (Fig. 5). Inferior volsella as in generic description. Gonostylus strongly inflated, widest distally, with slightly curved inner margin and outer margin curved, 136-185 [185] long. HR 0.71-0.99 [0.71]; HV 1.66-2.50 [2.34].

Pupa ( $n=5$ ) (Figs 6-8). Length. Total 3.30-3.52 $\mathrm{mm}$, cephalothorax $0.78-0.86 \mathrm{~mm}$, abdomen $2.46-2.70$ $\mathrm{mm}$. General coloration pale brown.

Cephalothorax. Coloration as in generic description. Dorsum of thorax moderately granulose. Frontal apotome as in Figure 6. Thoracic horn arising from a circular base with at least two branches (Fig. 7). Wing sheath without nose and pearls. Prealar tubercle absent. Setation as in generic description.

Abdomen (Fig. 8). Dorsal shagreen on T II-VI subquadrate, with the median area bare; shagreen spines anteriorly, spinules posteriorly and points in the mid area. Segments VII and VIII without shagreen. Posterior margin of T II with transverse row of 22-30 hooklets. T V-VII with 4 taeniae, T VIII with 5 equally sized lamellar lateral setae. Intersegmental conjunctives: III/IV with 20-36 and IV/V with 40-51 (4) spinules. Caudolateral comb on T VIII with 2 or 3 spurs and additionally with small basal spurs (Fig. 9). Anal lobes with 22-24 setae. DR 1.64-2.40.

Fourth instar larva $(n=4)$ (Figs 10-16). Head. Antennae with six segments, Lauterborn organs placed on apices of segments 2 and 3, style on segment 3 apparently absent (Fig. 10). Length of antennal segments: 74-83; 17-21; 19-22; 16-21; 10-11; 6-8. AR 1.01-1.09. Labrum with SI plumose, fused basally; SII large and fringed; SIII hairlike, basal pedestal present. Premandible with 2 apical teeth (Fig. 13); pecten epipharyngis with 6-7 

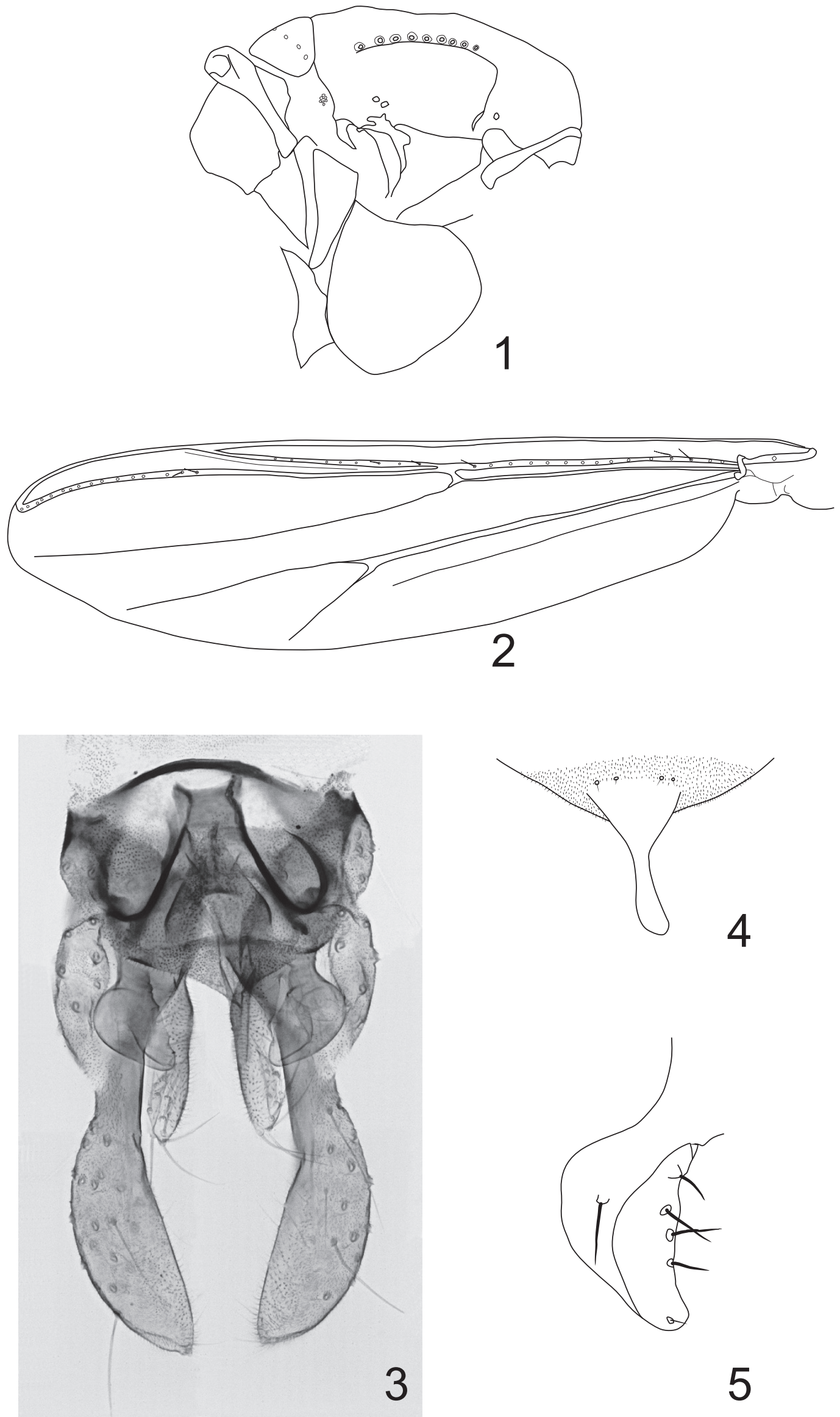

3

5

Figs 1-5. Apedilum griseistriatum comb. nov., male imago: 1, thorax, lateral view; 2, wing; 3, hypopygium; 4, anal point; 5, superior volsella. 

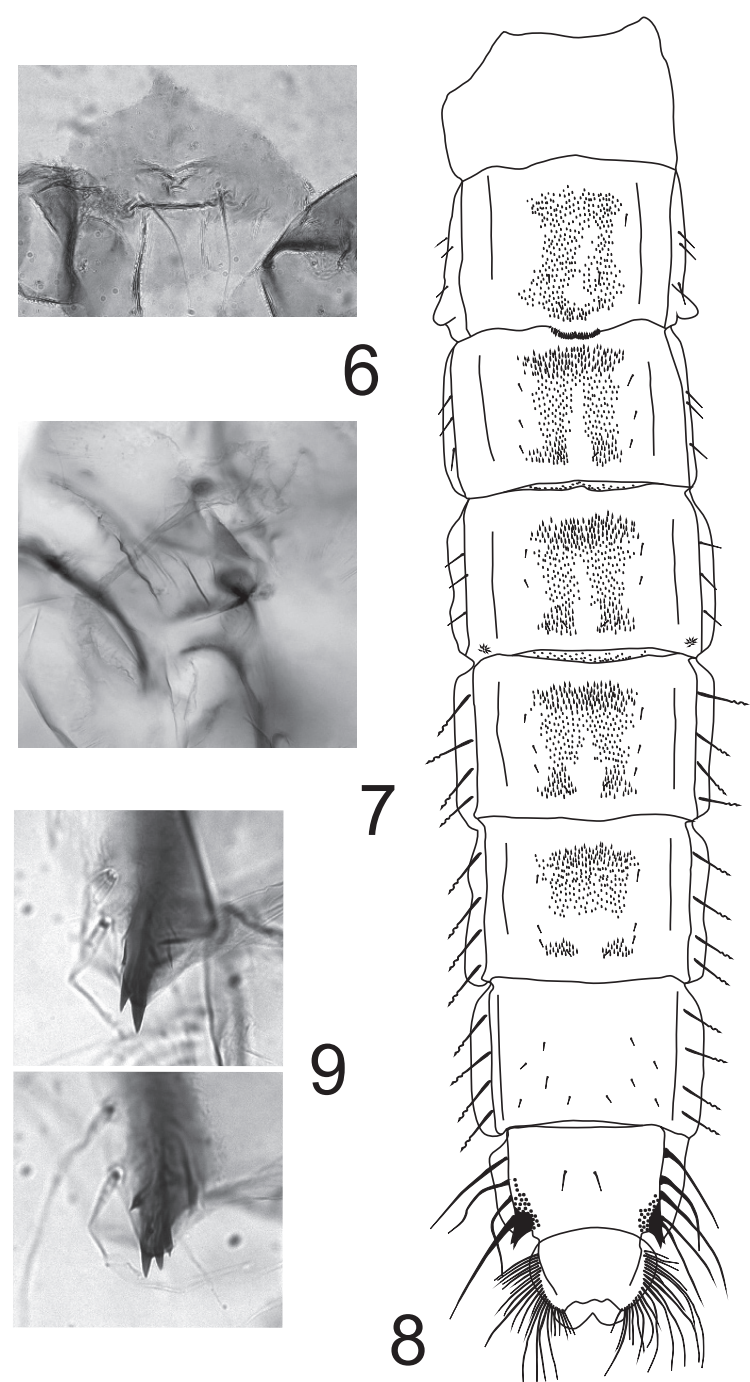

Figs 6-9. Apedilum griseistriatum comb. nov., pupa: 6, frontal apotome; 7, thoracic horn; 8, abdomen, dorsal; 9, posterolateral comb of segment VIII .

teeth (2) (Fig. 14). Mandible length 123-127, apical tooth pale, dorsal tooth and inner teeth dark (Fig. 11). Pecten mandibularis with 7-9 setae. Mentum with deeply bifid pale median tooth and 6 pairs of darker lateral teeth, $1^{\text {st }}$ lateral teeth small and appressed to $2^{\text {nd }}$ lateral teeth as in generic description, width 105-110, ventromental plate (Figs. 12) width 39; length 88-91; with 74-81 maxillary plate striae. Postmentum length 123-152. Labral sclerites and frontal apotome similar to A. elachistum (Fig.15). VPR 0.43-0.44; IPD 27-37; PSR 1.05-1.44.

Subfossil larvae ( $n=15$ except when otherwise stated). Head (Fig. 16). Postmentum length 136-151 (12). Mandible length 113-136 (13). Pecten mandibularis with 6-12 setae. Mentum width 93-110. Ventromental plate width 35-43; length 72-90; with 68-82 maxillary plate striae. VPR 0.40-0.57; IPD 23-38; PSR 0.92-1.65. Length of antennal segments: 72-81; 17-23 (14); 14-23 (14); 12-17 (14); 9-12 (14); 6-9 (14). AR 0.92-1.23 (14).

Remarks. Subfossil head capsules of Apedilum were recovered from sediment cores from Laguna Stibnite $\left(46^{\circ} \mathrm{S}\right.$, Chile) and Lago Nahuel Huapi, Blest branch $\left(41^{\circ} \mathrm{S}\right.$, Argentina). The $11 \mathrm{~m}$ core covers the period from the present to about 17,000 calendar years ago. Apedilum was found at ca. $2 \mathrm{~m}$ depth matching an age of 2,500 calendar years old. In Lago Nahuel Huapi, fossil specimens of the genus were found in several samples of a 2,000 years BP core. After the comparison of these morphotypes with the modern specimens of Apedilum found in northern Patagonia, we concluded they are the same species. The abundance of fossil head capsules from the lake sediment sequence were insufficient to make any interpretation about its ecology, however the species was found associated with Limnophyes, Labrundinia, Chironomus and Parachironomus (MASSAFERRO \& BROOKS 2002). In that study, the presence of these littoral/warm assemblages was interpreted as a change in the water level caused by a decrease in the precipitation regime. Likewise, in Lago Nahuel Huapi, fossil Apedilum was found in littoral areas together with orthoclads such as Limnophyes, Chaetocladius and Cricotopus. In northern Patagonia $\left(41^{\circ} \mathrm{S}\right)$ Apedilum was found in modern samples of Lago Los Clavos (1200 m a.s.1.), Lago Nahuel Huapi shore near Puerto Blest, Lago Gutierrez, Lago Espejo (ca. 800 m a.s.l.) and Lago Futalaufken (900 $\mathrm{m}$ a.s.1.). These lakes are located in the Subantarctic province following the biogeographic schemes proposed by CABRERA \& WilLINK (1973). This biogeographic province has a strong precipitation gradient from west to east, with about $5,000 \mathrm{~mm}$ per year in Chile and $700-800 \mathrm{~mm}$ per year in Argentina due to the influence of the Andean Cordillera. These findings suggest the new species prefers littoral zones of deep lakes such as Nahuel Huapi and Gutierrez and shallow lakes such as Los Clavos. Further studies are needed to understand fully the ecological requirements of this species.

\section{DISCUSSION}

EDWARDS (1931) described griseistriatum in the subgenus Chironomus (Polypedilum) together with the species quinquesetosum according to the current classificatory system for that time. SPIES \& ReIss (1996) transferred quinquesetosum to the genus Polypedilum Kieffer and recently this species was placed in the subgenus Polypedium (Tripodura) by Fuentes \& Donato (2014). The new combination Apedilum griseistriatum proposed here is based on the possession of this unique combination of diagnostic male characters for the genus Apedilum that is: antennae with 13 flagellomeres, apex of fore tibia truncated, squama bare and superior volsella globose.

The pupa of Apedilum is difficult to diagnose between those Chironomini pupae with few branches on the thoracic horn. In the identification key of COFFMAN \& Ferrington (1996), Apedilum keys to Stelechomyia Reiss because is erroneously described as having cephalic tubercles (JACOBSEN, 2008). CRANSTON et al. (1989) does not include Apedilum, but in a pass through their key 

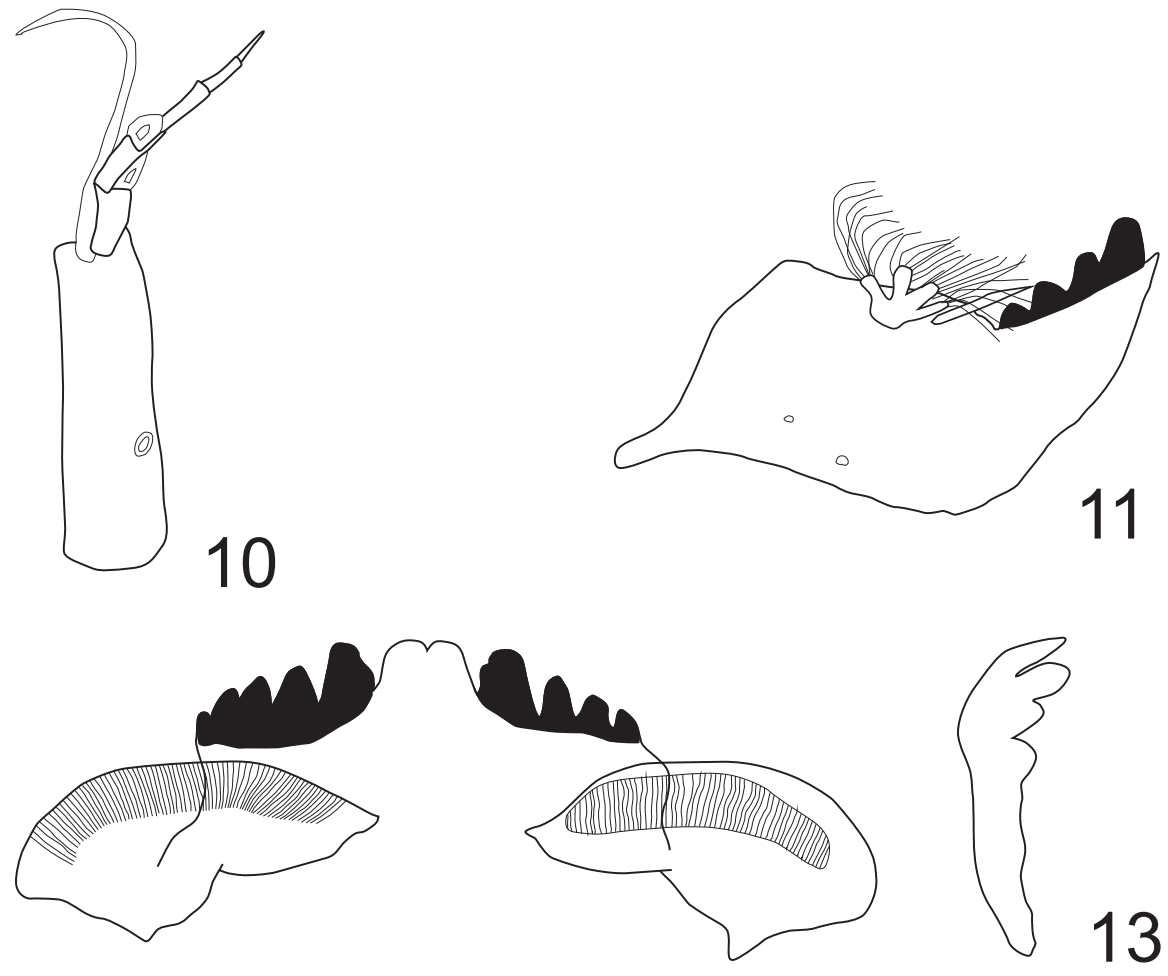

12
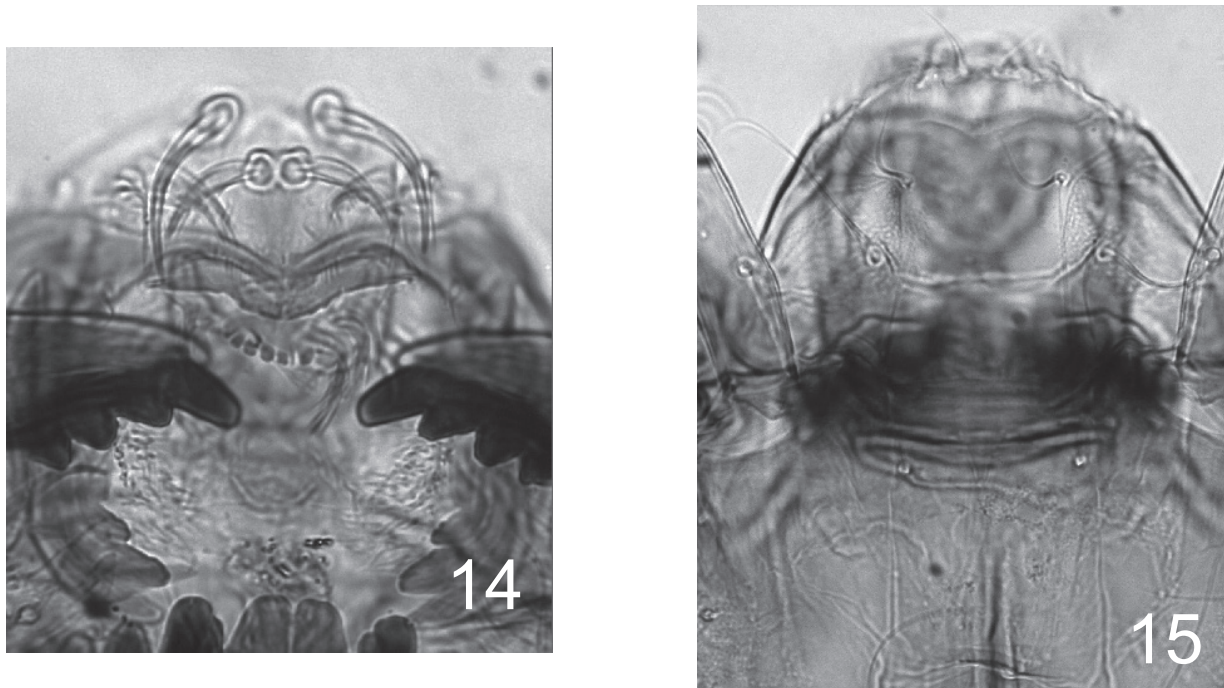

Figs 10-15. Apedilum griseistriatum comb. nov., fourth instar larvae. 10, antennae; 11, mandible; 12 , mentum with ventromental plate; 13, premandible; 14, pecten epipharyngis; 15, labral sclerites and frontal apotome.

this genus identifies as Paralauterborniella. The unique combination of pupal characters for Apedilum such as cephalic tubercles absent, hook row on T II continuous, no more than 4(6?) branches in the thoracic horn, frontal setae present, caudolateral spurs on T VIII single or with small basal spurs, abdominal segments V-VII with four lamellar setae and segment VIII with five lamellar setae are present in the new combination here proposed. From the genera postulated as closely related to Apedilum by EPLER $(1988,1996)$, Paralauterborniella is separable by presence of cephalic tubercles and a blunt nose on the wing sheath;
Zavreliella by the presence of cephalic tubercles, presence of paired patches of short points on tergites II-VI, and 4 lateral setae on T VIII; and Oukuriella by the presence of wrinkled cephalic tubercles and 4 lateral setae on T VIII.

The tentative larval stage proposed in this study for $A$. griseistriatum comb. nov. possess the diagnostic combination of characters for the genus Apedilum: S I with bases fused medially; S II with short basal segment; pecten epipharyngis a single plate; 6 segmented antenna, with alternate Lauterborn organs; mentum with pale bifid median tooth, and first lateral teeth reduced and adpressed 


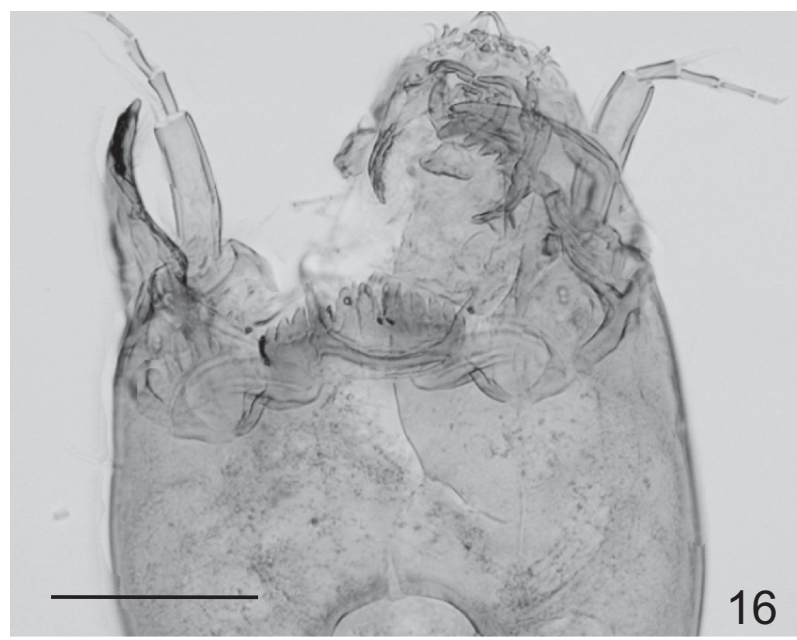

Fig. 16. Apedilum griseistriatum comb. nov., subfossil head capsule. Scale bar $100 \mu \mathrm{m}$.

to larger second lateral teeth; well developed maxillary plate striations; and mandible with dorsal teeth (EPLER, 2001).

Apedilum griseistriatum comb. nov. has almost all the characters described by EPLER (1988) as diagnostic for Apedilum but there are some additional characters which emend the diagnosis for the genus. Such characters are: the adult male has wing length $1.1-2.47 \mathrm{~mm}$, superior volsella with microtrichia dorsally and ventrally or without microtrichia, the gonostylus moderately to strongly inflated, sensilla chaetica present on the metatarsus of the middle leg, confined to apical $1 / 5$, and sometimes present on apical $1 / 5$ of hind metatarsus, or absent on all metatarsi. The larva has a greenish-gold or red body in life.

Within the genus, A. griseistriatum comb. nov. appears most closely related to $A$. subcinctum since in both species the caudolateral comb of T VIII in the pupae consists in a group of small spurs. In the adult of both species, the wing is not spotted and in A. griseistriatum comb. nov. an anal point is present but in $A$. subcinctum the anal point may be well-developed or absent.

Key to males of Apedilum Townes

1. Wing with pale spots Apedilum elachistum

1 '. Wing without pale spots ... 2

2. Gonostylus moderately inflated. Anal point absent or, if present, its length is smaller than the maximum width of superior volsella . Apedilum subcinctum

2'. Gonostylus strongly inflated. Anal point always present, its length is greater than the maximum width of superior volsella Apedilum griseistriatum comb. nov.

\section{Key to pupae of Apedilum Townes}

1. Caudolateral angle of T VIII with one large spur or large spur with smaller basal spurs .... Apedilum elachistum

1'. Caudolateral angle of T VIII with group of small spurs . 2

2. T VII and VIII with rounded anterolateral shagreen areas; dorsal shagreen on T II-VI subquadrate and continuous;
T VIII with 1 lateral seta thinner than other Apedilum subcinctum

2. T VII and VIII without shagreen; dorsal shagreen on T II-VI subquadrate, median area bare; T VIII lateral setae of equal width .. Apedilum griseistriatum comb. nov.

Key to larvae of Apedilum Townes

1. Ventromental plate with 74-81 maxillary plate striae ....... . Apedilum griseistriatum comb. nov. 1 '. Ventromental plate with more striae on maxillary plate. 2 2. 90 - 105 maxillary plate striae ... Apedilum elachistum 2'. 110 - 125 maxillary plate striae ... Apedilum subcinctum

Acknowledgements. We would like to thank the Darwin Initiative (DEFRA, UK) for providing funds to carry out this work (project $\# 15 / 025$ ). We thank to the two anonymous reviewers for their invaluable comments and suggestions. Thanks also to Fernanda Montes de Oca, Analia Garre and the park rangers of Nahuel Huapi National Park for help with the field work. This paper is the Scientific Contribution \#961 of the Institute of Limnology "Dr. R. A. Ringuelet" (ILPLA, CCT-La Plata, CONICET, UNLP).

\section{REFERENCES}

Cabrera, A. L. \& Willink, A. 1973. Biogeografía de América Latina. Washington D.C., OEA (Monografía n ${ }^{\circ} 13$, Serie Biología). 109p. Coffman, W. P. \& Ferrington, L. C, JR. 1996. Chironomidae. In: Merritt, R.W. \& Cummins, K.W. eds. An introduction to the aquatic insects of North America. 3ed. Dubuque, Kendall/Hunt Publishing, p. 635-754.

Cranston, P. S.; Oliver, D. R. \& SÆther, O. A. 1989. The adult males of Orthocladiinae (Diptera: Chironomidae) of the Holarctic region - keys and diagnoses. Entomologica Scandinavica (Suppl) 34:165-352.

Donato, M.; PAGGi, A. C. \& Epler, J. H. 2008. New record, geographic variation and redescription of Apedilum elachistum Townes (Diptera: Chironomidae: Chironominae), Studies on Neotropical Fauna and Environment 43(2):125-134.

EDWARDS, F. W. 1931. British non-biting midges (Diptera, Chironomidae). Transactions of the Royal Entomological Society of London 77:279-430.

EpLer, J. H. 1987. Revision of the Nearctic Dicrotendipes Kieffer, 1913 (Diptera: Chironomidae). Evolutionary Monographs 9:1-102. .A reconsideration of the genus Apedilum Townes, 1945 (Diptera, Chironomidae). Spixiana Supplement 14:105-116. 1996. New species of Oukuriella (Diptera: Chironomidae) from Costa Rica. Hydrobiologia 318:3-11.

. Identification Manual for the larval Chironomidae (Diptera) of North and South Carolina. A guide to the taxonomy of the midges of the southeastern United States, including Florida. Special Publication SJ2001-SP13. Raleigh, North Carolina Department of Environment and Natural Resources and Palatka, St. Johns River Water Management District. 526p.

Fuentes, M. C. \& Donato, M. 2014. Review of taxonomic status of Polypedilum quinquesetosum (Edwards, 1931) (Diptera, Chironomidae). Revista de la Sociedad Entomológica Argentina 73(3-4):139-144.

Jacobsen, R.E. 2008. A Key to the Pupal Exuviae of the Midges (Diptera: Chironomidae) of Everglades National Park, Florida. Ft. Lauderdale, U. S. Geological Survey Scientific Investigations Report 2008-5082. 119p.

Lenz, F. 1941. Die jugendstadien der Sectio Chironomariae (Tendipedini) connectentes (Subf. Chironominae $=$ Tendipedinae). Zusammenfassung und Revision. Archiv für Hydrobiologie 38: 1-69.

Massaferro, J. \& Brooks, S. J. 2002. The response of Chironomids to Late Quaternary environmental change in the Taitao Penninsula, Southern Chile. Journal of Quaternary Sciences 17(2):101-111. 
Roвack, S. S. 1957. The immature tendipedids of the Philadelphia area. Monographs of the Academy of Natural Sciences of Philadelphia 9:1-152.

SÆTHER, O. A. 1980. Glossary of chironomid morphology terminology (Diptera: Chironomidae). Entomologica Scandinavica Supplement 14:1-51.
Spies, M. \& Reiss, F. 1996. Catalog and bibliography of Neotropical and Mexican Chironomidae (Insecta, Diptera). Spixiana Supplement 22:61-119.

Townes, H.K. 1945. The Nearctic species of Tendipedini, American Midland Naturalist 34:1-206. 